\title{
METHOXYFLURANE: EFFECTS UPON CARDIAC CONTRACTILITY, RHYTHMICITY, AND BLOOD PRESSURE IN DOGS ${ }^{\circ}$
}

\author{
Roger Brassard, M.D., Clayton A. Johnson, B.s., $f$ \\ Joseph J. BuCkLeY, M.D., AND James H. MatThews, M.D.
}

THES STUDY was undertaken to clarify some of the contradictory information that has appeared concerning the haemodynamic effects of methoxyflurane. Artusio introduced the agent into clinical use in $1960^{1,2}$ after experiments with animals demonstrated that circulation and respiration were well maintained. ${ }^{3}$ Subsequent investigations in $\operatorname{dogs}^{4,5,13}$ and $\operatorname{man}^{6}$ did not consistently confirm this early work, but such wide variations existed in methods of administration and evaluation of the drug that results are difficult to interpret. For example, Siebecker et al. ${ }^{5}$ showed that methoxyflurane produced significant depression of respiration and acidaemia; yet many studies designed to assess the cardiac effects of methoxyflurane fail to control this variable, which profoundly influences cardiovascular dynamics. ${ }^{7}$ The experiments reported herein were designed' to eliminate as many variables as possible in order to delineate the cardiovascular effects of this new compound.

\section{Procedure}

Thirty unselected mongrel dogs ranging in weight from 6.7 to $26.0 \mathrm{~kg}$. (average $13.0 \mathrm{~kg}$.) were studied. Without premedication, each dog was anaesthetized intravenously with $15-20 \mathrm{mg}$. $/ \mathrm{kg}$. of methohexital sodium; the trachea was intubated with a cuffed orotracheal tube. The animal then was placed in the right lateral recumbent position and the endotracheal tube was connected to a precision volume respirator which delivered 100 per cent oxygen at 22 cycles per minute. The tidal volume was adjusted so that the end-expiratory $\mathrm{CO}_{2}$ was maintained at 5.6 per cent throughout the procedure. A polyethylene catheter was inserted through the femoral artery into the abdominal aorta and was attached to a pressure transducer. Through a thoracotomy in the left fifth interspace, a sirain gauge arch was sutured to the left ventricle, according to the method of Boniface et al. ${ }^{8}$ The connecting wires were led outside the chest, the lung was inflated, and the thoracotomy was closed. ECG and EEG needle electrodes were applied. Then the dog was allowed to recover until he began to struggle and until the EEG revealed low-voltage fast activity. At this point, recordings of cardiac contractile force, aortic blood pressure, electrocardiogram, and electroencephalogram were made; these data served as controls for the remainder of the experiments.

Methoxyflurane was then introduced into the breathing system in 0.5 per cent

"From the Department of Anesthesiology, University of Minnesota Medical Center, Minneapolis 14, Minnesota.

$\nmid$ Medical Student Research Assistant, supported by Public Health Service Medical Student Training Grant No. 2R-24 (C3), from the Division of General Medical Sciences, Public Health Service. 
concentration for 15 minutes; the concentration was increased every 15 minutes thereafter by 0.5 per cent until a maximum of 2 per cent was attained. This stepwise process was then reversed and the animal was allowed to recover until he struggled and manifested EEG control activity. All functions were recorded continuously at a paper speed of $0.5 \mathrm{~mm}$./ sec. Following 15 minutes' exposure to each incremental and decremental concentration a fast recording at $25 \mathrm{~mm}$. $/ \mathrm{sec}$. was made. This entire routine was designated Run A. The procedure was repeated in 12 dogs to determine whether cumulative effects of methoxyflurane were detectable. This was designated Run B.

\section{Methods}

Artificial respiration was provided by a Harvard Respirator via a non-rebreathing system. End-expiratory carbon dioxide was measured by a Beckman LB1 Medical gas analyser with a breathe-through cell. The output signal was recorded continuously by a Texas Instruments Rectilinear recorder. Aortac blood pressure was measured with a Statham strain gauge, model P23D. Myocardial contractile force was measured by a 120-ohm Walton-Brodie strain gauge arch. Limb lead II electrocardiographic recordings were made continuously according to the method of Lannek. ${ }^{9}$ Electroencephalographic recordings were obtained from bipolar needle electrodes $5 \mathrm{~cm}$. apart in a left fronto-occipital position with a ground electrode over the right"parietal area. A calibration of 100 microvolt $=2.0$ $\mathrm{cm}$. deflection was employed. The latter four signals were led to appropriate preamplifiers and recorded by a Sanborn Model 150 multichannel recorder.

A special vaporization system was designed to deliver accurate, reproducible concentrations of methoxyflurane (Fig. 1). Oxygen flowed through control valve 1 and through a conventional copper kettle containing approximately 125 c.c. of

SCHEMATIC OF ANESTHESIA DELIVERY SYSTEM

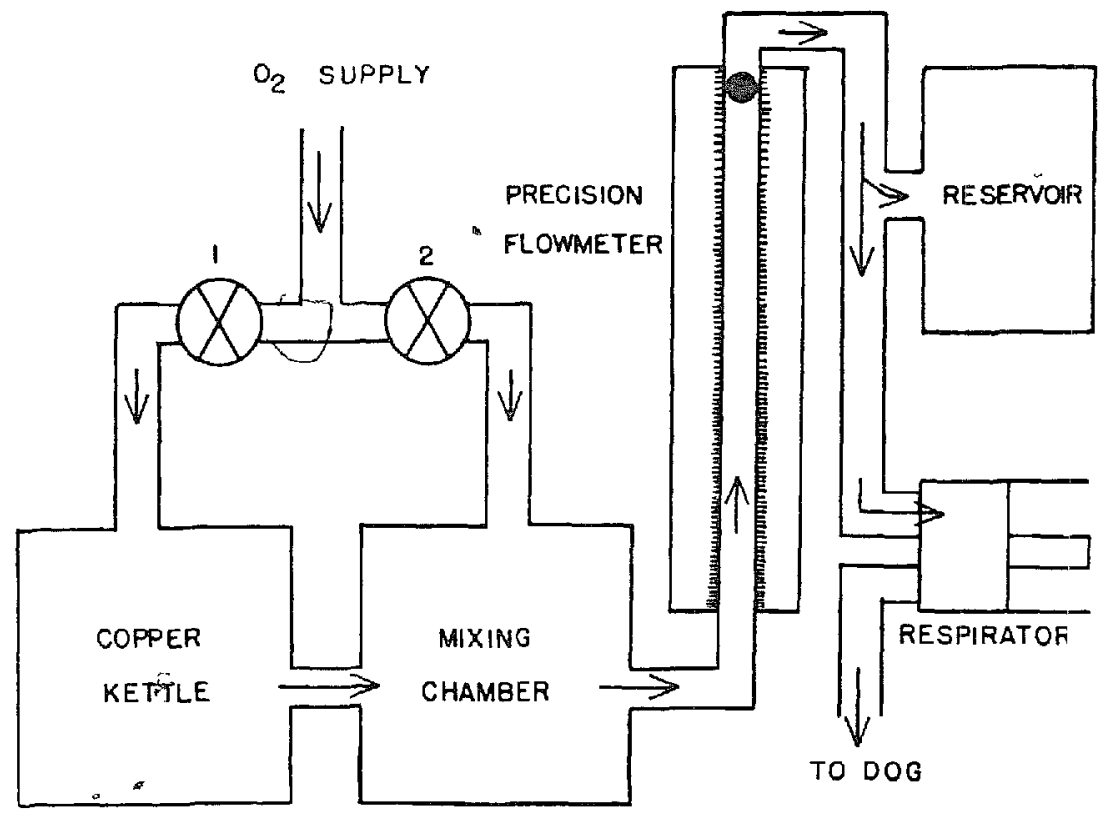

Fict RE L 
methoxyflurane. The temperature of the liquid within the kettle was measured with a Dillon aneroid thermometer. The effuent mixture then passed through a mixing chamber and a calibrated Tri-Flat precision flowmeter to a reservoir bag. Diluent oxygen was added via control valve 2 to the atmosphere of the mixing chamber so as to produce a total flow through the flowmeter of $6650 \mathrm{ml} . / \mathrm{min}$. The ratios of kettle flow to diluent flow were yaried according to precalculated values (Table I) to provide the appropriate concentrations of methoxyflurane.

TABLE $\mathrm{F}$

Methoxyflurane Concentration Chart

\begin{tabular}{ccccc}
\hline $\begin{array}{c}\mathrm{O}_{2} \text { flow } \\
\text { through kettle, } \\
\text { c.c. } / \text { min. }\end{array}$ & $\begin{array}{c}\text { Methoxyllurane } \\
\text { vapour, } \\
\text { c.c. } / \mathrm{min} .\end{array}$ & $\begin{array}{c}\text { Diluent } \mathrm{O}_{2 /}, \\
\text { c.c./min. }\end{array}$ & $\begin{array}{c}\text { Total flow, } \\
\text { c.c. } / \text { min. }\end{array}$ & $\begin{array}{c}\text { Per cent } \\
\text { methoxyflurane }\end{array}$ \\
\hline 997.50 & 33.25 & 5619.25 & 6650 & 0.5 \\
1995.0 & 66.50 & 4588.5 & 6650 & 1.0 \\
2992.5 & 99.75 & 3557.75 & 6650 & 1.5 \\
3990 & 133.00 & 2527 & 6650 & 2.0 \\
\hline
\end{tabular}

${ }^{\star}$ Kettle Temperature $=21.7^{\circ} \mathrm{C}$.

+Vapour pressure at $21.7^{\circ} \mathrm{C} .=24.65 \mathrm{~mm}$. $\mathrm{Hg}$.

Average atmospheric pressure in Minneapolis $=745 \mathrm{~mm}$. $\mathrm{Hg}$.

\section{Results}

Where appropriate, the changes observed in the thirty dogs are averaged and the results are expressed as the percentage of the control values.

Myocardial contractile force (Fig. 2). In Run A the contractile force decreased as the concentration of methoxyllurane increased, falling to 52 per cent of the control value after exposure to the 2 per cent mixture. Upon decremental withdrawal of the agent, a lag in the recovery of myocardial contractility occurred. Significant recovery trends were not observed until after exposure to the 0.5 per cent concentration. After 30 minutes of 100 per cênt oxygen breathing (complete

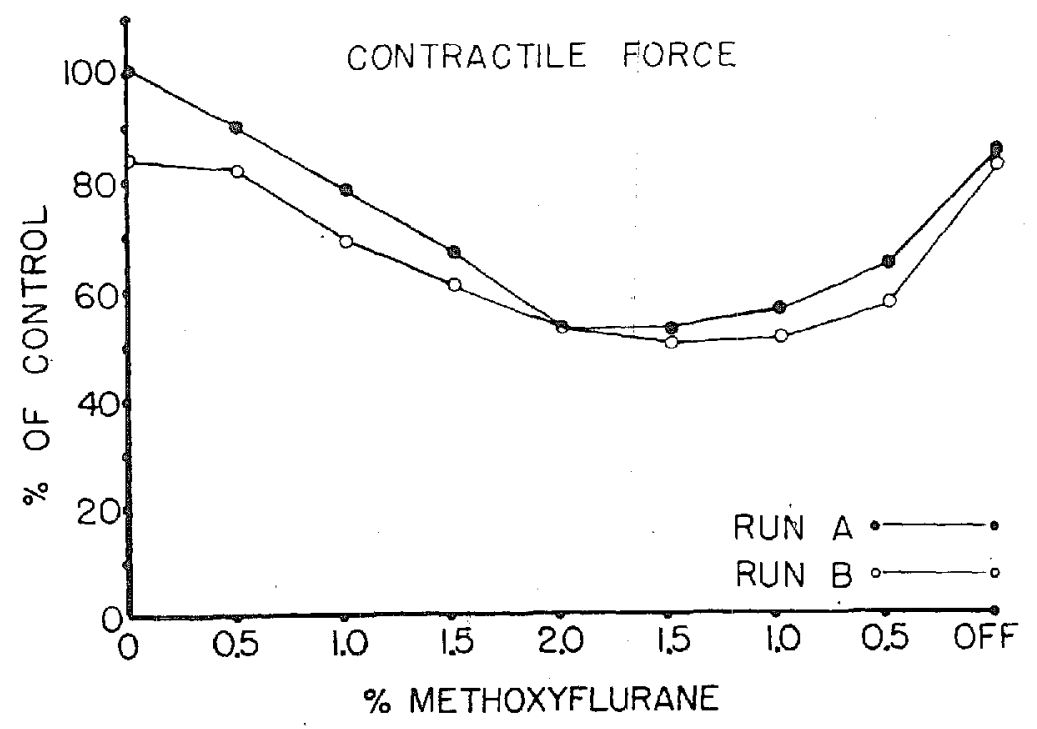

Figure 2. 
withdrawal of methoxyflurane), the myocardial contractile force remained depressed 15 per cent.

During Run B, even though the contractile force was partially depressed at the beginning, the same increases in concentration did not depress contractility to a greater extent than had occurred in Run A but the depression plateau remained for a longer period of time.

Systolic blood pressure (Fig. 3). The systolic blood pressure followed essentially the same pattern of depression and recovery; the per cent changes were almost identical with those which occurred in the contractile force.

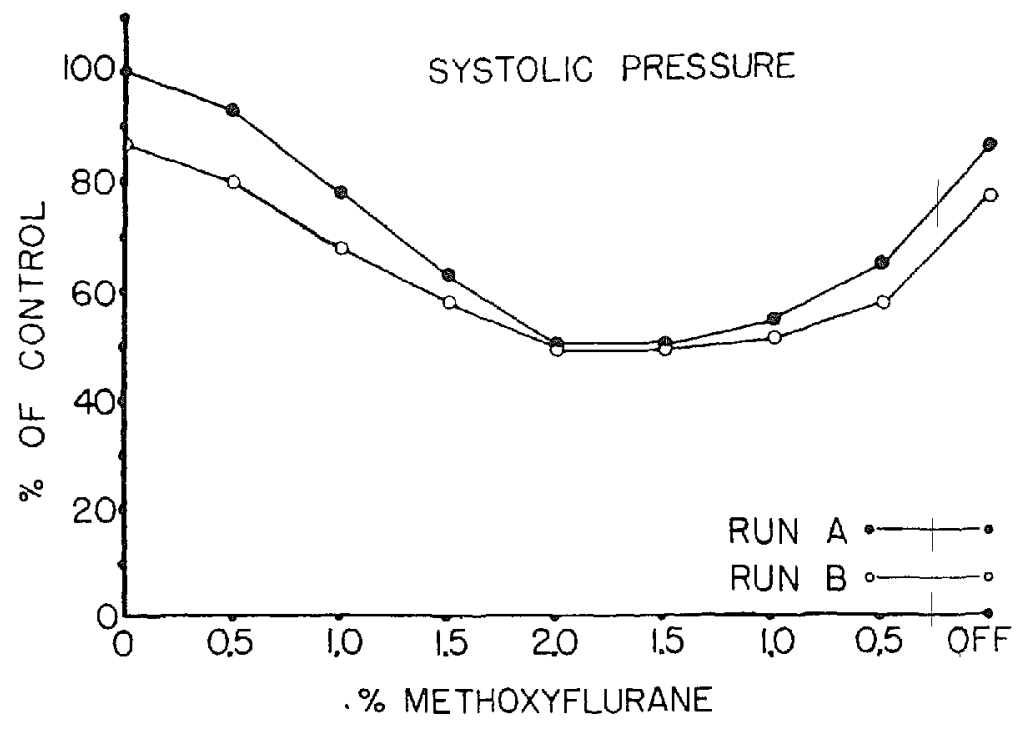

Ficure 3.

Diastolic blood pressure (Fig. 4). The diastolic blood pressure decreased to 45 per cent of the initial level in response to 2 per cent methoxyllurane and recovery was delayed slightly longer. At the end of both runs the diastolic pressure had not returned to its original value.

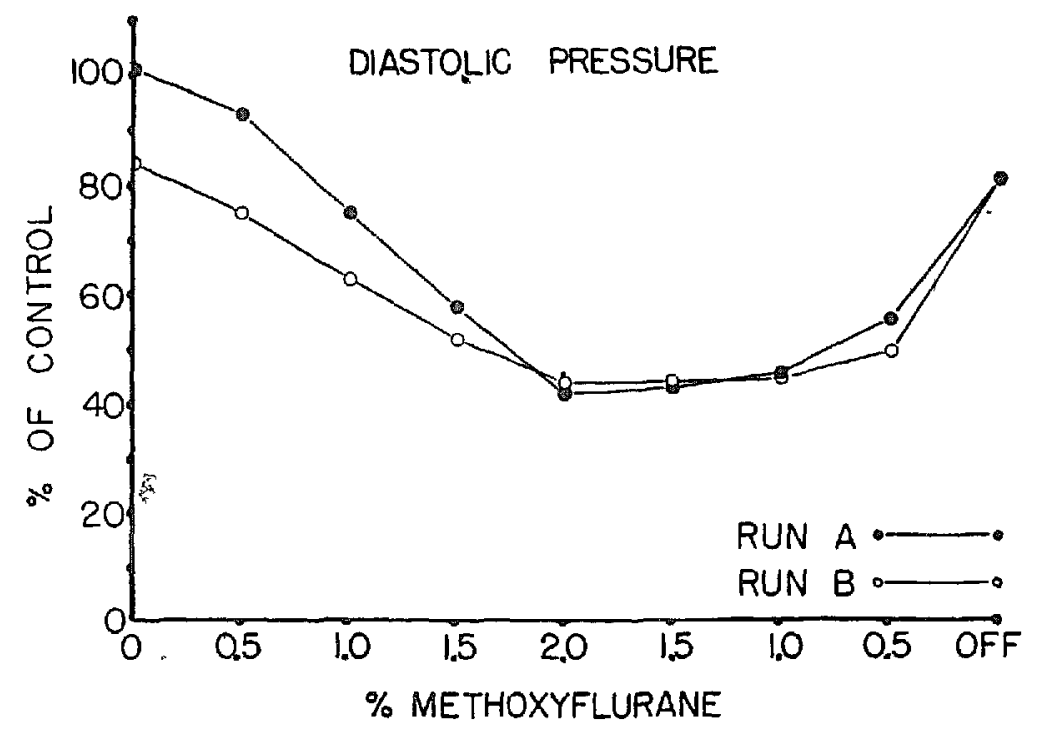

Figure 4. 


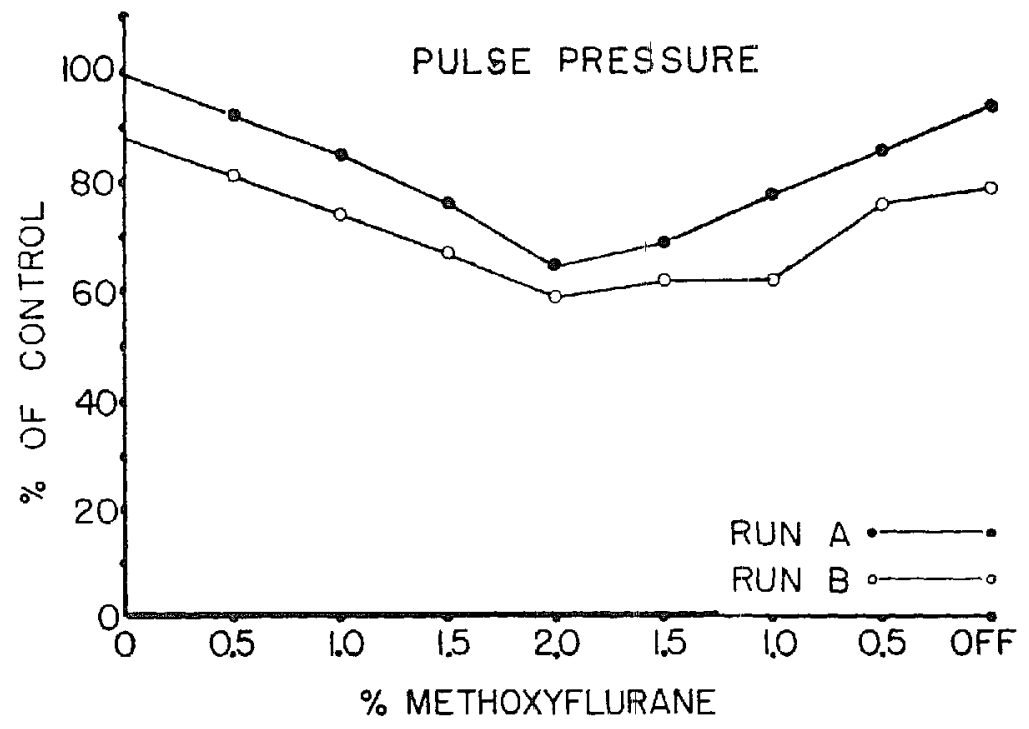

Figure 5.

Pulse pressure (Fig. 5). The pulse pressure decreased moderately during Run A (65 per cent of control value at maximum concentration) and further depression occurred during Run $B$.

Heart rate and rhythm (Fig. 6 ). The heart rate decreased progressively as the concentration of the agent increased. At the end of Run $A$, the rate was 80 per cent of the control value. During Run B there was a very slight trend towards a further decrease in heart rate.

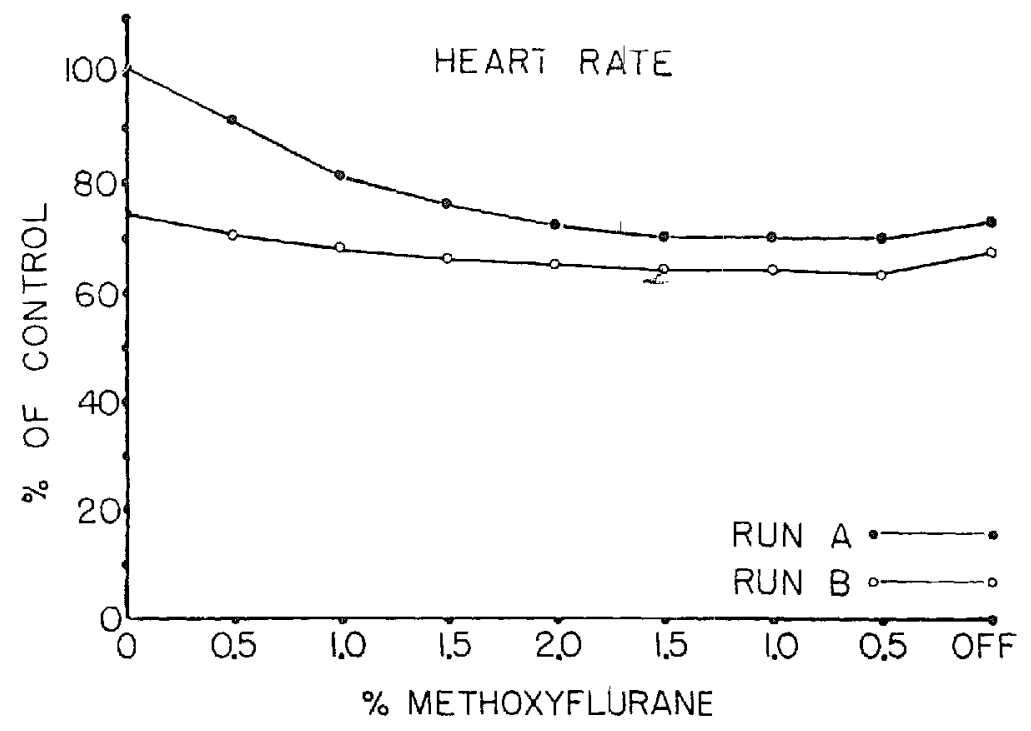

Figure 6.

Usually the heart rhythm during methoxyflurane anaesthesia was regular. Sinus bradycardia was common. Four of the 30 dogs had cardiac rhythm disturbances. Bigeminy appeared during inhalation of 0.5 per cent methoxyllurane in one of the animals; another had ventricular extrasystoles at this concentration. Both arrythmias cleared spontaneously as the depth of anaesthesia increased. One instance of 
wandering pacemaker occurred during deep anaesthesia; this disappeared during emergence. One animal developed idioventricular rhythm, which progressed to ventricular fibrillation following severe hypotension.

Electrocardiogram. The following electrocardiographic data were observed at the end of the 2 per cent methoxyllurane exposure period. The $P$-wave voltage decreased in 70 per cent of the tracings; the voltage was restored in half of these after withdrawal of methoxyflurane for 30 minutes. The $R$-wave voltage decreased

\section{METHOXYFLURANE}

E.E.G

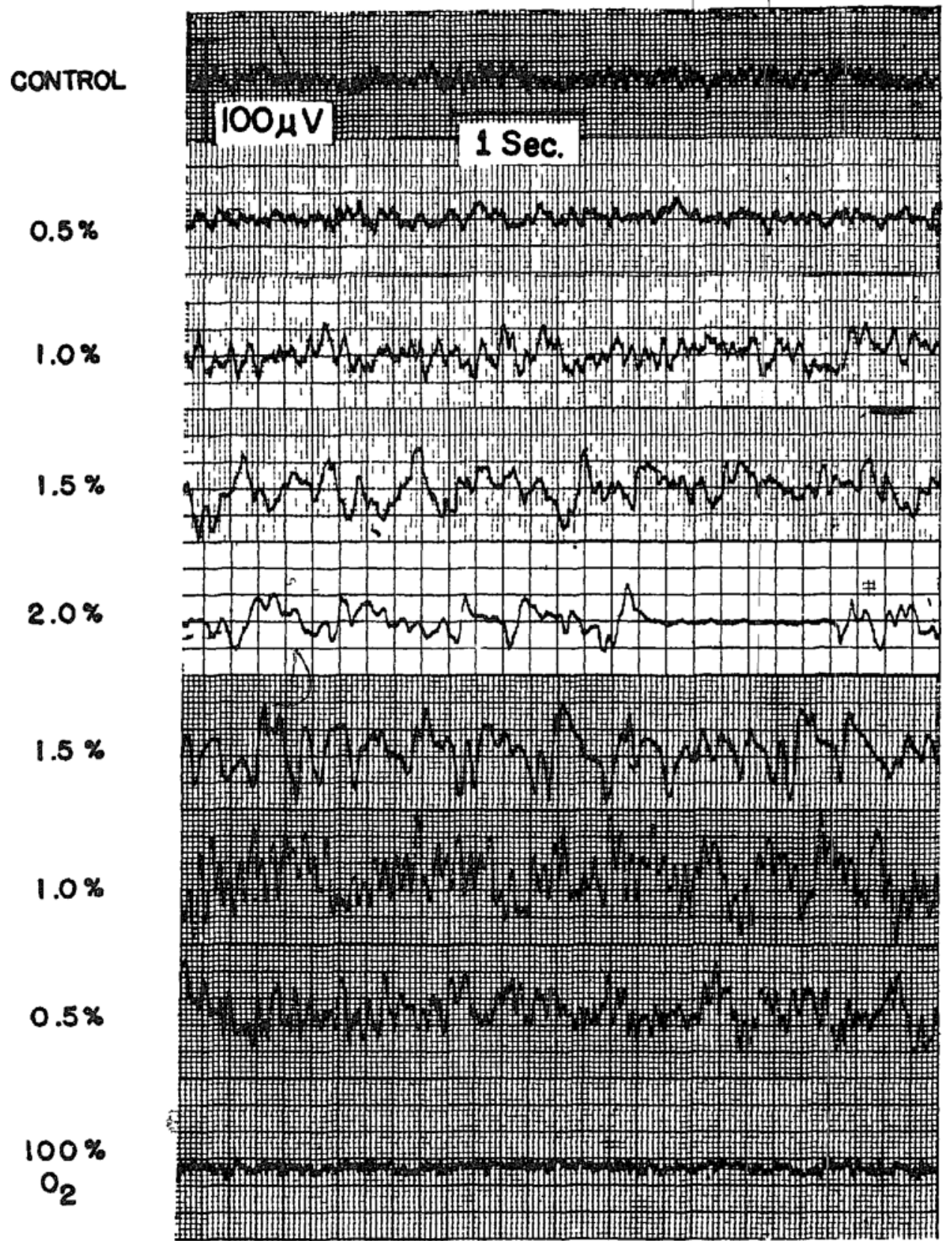

Figure 7. 
in 40 per cent of the records. Prolongation of the $P R$ interval occurred in 20 instances (47\%), but in only three was this significant. $S T$ depression occurred 15 times (35\%). The QT interval showed prolongation in 50 per cent of the tracings. Alteration of the $T$ wave occurred in all instances; tracings with upright control $T$ waves manifested inversion and those normally inverted showed deeper inversion. Partial recovery of $T$-wave voltage was evident in 63 per cent of the electrocardiograms 30 minutes after administration of the drug was stopped.

Electroencephalogram. As depth of anaesthesia increased, low-voltage fast activity changed to slower (10-15 c.p.s.) waves with higher voltage. Spindle forms did not appear. In deeper stages superimposed fast activity disappeared. The greatest amount of cerebral depression produced slow (1-2 c.p.s.), high-voltage (50-100 microvolt) wave forms, sometimes interrupted by burst suppression lasting up to 5 seconds.

Figure 7 shows tracings typical of most records obtained serially at the end of each 15-minute exposure period during Run A. Occasional deviations from these patterns occurred, and in a few instances this appeared to be related to the size of the animal. The EEG exhibited a delay in recovery similar to that which characterized changes in contractile force and blood pressure. This was most evident during withdrawal of the drug. Exposure to 2 per cent methoxyllurane produced burst suppression in 35 per cent of the tracings; at the end of the next 15-minute period, when the dogs were inhaling only 1.5 per cent vapour, burst suppression was present in 45 per cent of the records. Burst suppression was closely related to the severity of hypotension. When the blood pressure remained above $90 \mathrm{~mm}$. $\mathrm{Hg}$, burst suppression did not develop. When suppression was observed, the average systolic pressure was $66 \mathrm{~mm}$. $\mathrm{Hg}$.

\section{Discussion}

The control values employed in these experiments doubtless are influenced by a number of factors, prominent among which are the residual effects of methohexital and the effects produced when the animals were allowed to awaken to the point of reacting to the stimulation of the endotracheal tube and other appliances. It would seem reasonable to expect, however, that these two conditions would tend to offset one another; thus the control data, while in no way reflecting a steady state, provide practical points of reference for the subsequent measurements.

The duration of exposure to each incremental and decremental concentration was chosen somewhat arbitrarily, with the full realization that true equilibration did not occur. Initially, a 7-minute exposure period was tried, since this had proved satisfactory for similar experiments with halothane. However, it was readily apparent that haemodynamic responses did not stabilize during this interval; therefore the exposure time was doubled. The 15-minute period furnished satisfactory stabilization of cardiovascular function (Fig. 8).

A definite lag occurred in the recovery of all functions monitored during withdrawal of the agent. Thomason et al. ${ }^{10}$ have pointed out that methoxyflurane has a high water and oil solubility and that the body's capacity to store it is high. 


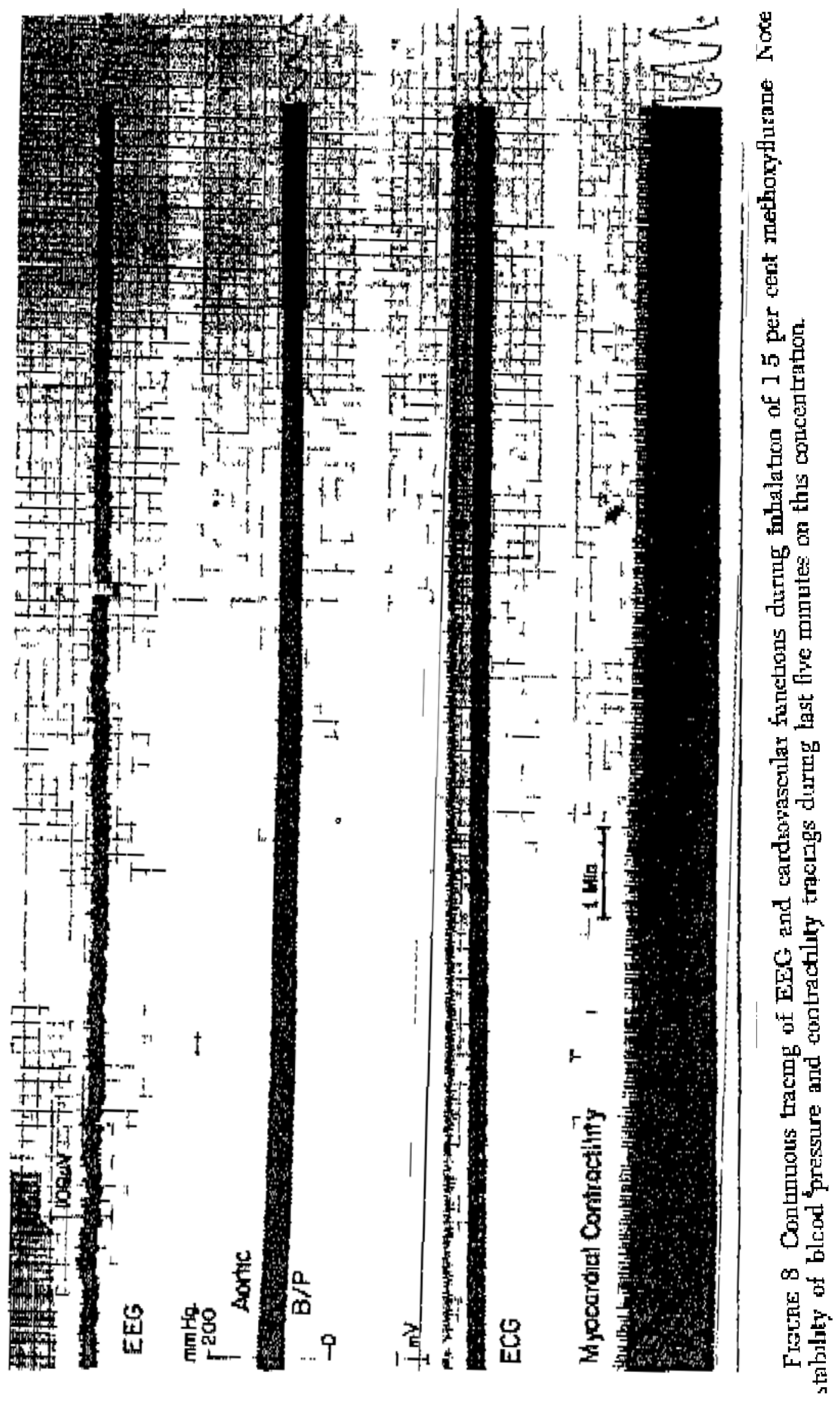


Wyant et al. ${ }^{12}$ noted that obese patients awakened more rapidly following prolonged methoxyflurane administration than did lean patients. He concluded that the blood concentration fell more rapidly when the agent could escape into abundant fatty deposits while at the same time it was being exhaled. The lean patient on the other hand must depend solely upon pulmonary exchange to reduce the blood concentration. The animals studied here were obtained directly from the supplier one or two days prior to the experiment; they tended to be malnourished and underweight. It seems likely that the slow recovery of haemodynamic functions observed in these lean animals is a reflection of the gradual reduction of blood and tissue stores primarily through alveolar excretion, with little or no reapportionment to fatty depots.

The myocardial contractile force measurements reported here are in general agreement with those of Bagwell et al. ${ }^{11}$ although our figures reveal somewhat less depression of contractility at the low concentrations of methoxyflurane. This disparity is understandable since the above workers induced anaesthesia with 3 per cent methoxyflurane and then reduced the inhaled concentration to lower levels for purposes of cardiovascular evaluation. In the light of the emergence lag described above, it is likely that tissue levels at each inhaled concentration were significantly higher in their animals than in ours.

Systolic and diastolic blood pressure and pulse pressure exhibited responses which paralleled myocardial contractility. These changes are indicative of the general cardiovascular depressant properties of this agent. Most noteworthy is the almost identical per cent changes observed for systolic pressure and myocardial contractility ( Fig. 9).

Rigid control of ventilation prevented the data trom being influenced by the effects of respiratory acidosis which occurs with spontaneous inhalation of this agent. $^{5}$ But our efforts to maintain the end expiratory concentration of carbon

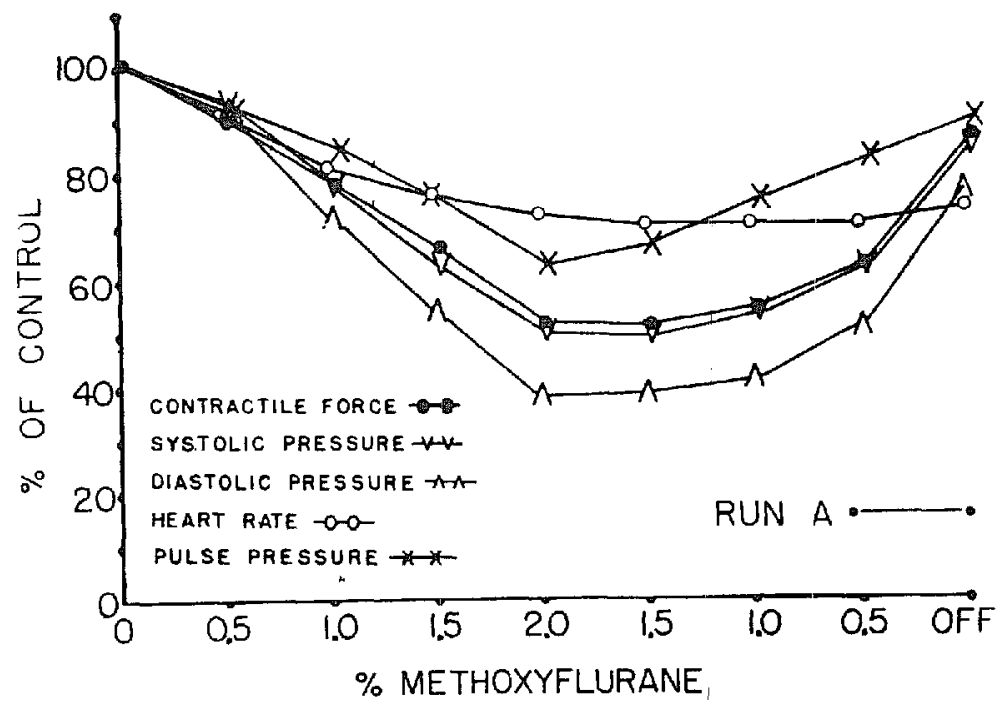

FIGURE 9. Composite graph of changes in cardiovascular functions observed during exposure to various concentrations of methoxyllurane. Note especially the parallel changes in contractility and systolic blood pressure (see text). 
dioxide at 5.6 per cent may have introduced effects traceable to the intermittent positive-pressure respiration. Wyant et al. ${ }^{12}$ showed that with methoxyflurane anaesthesia the total peripheral resistance decreased during spontaneous respiration and increased slightly above the initial value during controlled respiration. Since the pulse pressure showed a moderate decrease in our experiments, an incresase in peripheral resistance may have accompanied the artificial breathing during methoxyflurane anaesthesia. Bagwell's demonstration that sympathetic reflexes are still reactive during methoxyflurane anaesthesia ${ }^{\mathbf{1 1}}$ suggests that an autonomic response to pulmonary inflation is indeed possible in this circumstance.

The experience of some workers ${ }^{11,4}$ indicates that no significant change in pulse rate accompanies methoxyflurane administration. Our data show that in dogs a moderate sinus bradycardia occurs frequently and persists despite withdrawal of the agent. $P$-wave and $P R$-interval changes suggest that this bradycardia may be the result of vagal predominance. Abnormal rhythm was an infrequent occurrence in this study; this is in agreement with other studies in dogs and man. ${ }^{2,11} 12,13$

The T-wave alterations constituted one of the most constant and striking findings of the study. This has not been described previously. It is interesting to note that the $T$-wave changes occurred even during the administration of low concentrations of methoxyflurane and at a time when myocardial contractility and blood pressure were minimally depressed. We have no explanation for this finding, which suggests that some change in the repolarization occurred.

The unusual amount of EEG burst suppression is an interesting finding. It is absent in most previous studies in $\operatorname{man}^{2,6,14}$ probably because the blood pressure of the subjects was not allowed to reach such hypotensive levels. However, Knox et $a .^{15}$ published a graph taken from one human subject which showed burst suppression despite a normal blood pressure. We feel that the appearance and duration of burst suppression in this series correlates well with reduced systolic blood pressure, pulse pressure, and contractile force.

\section{SUMMARY}

Methoxyflurane was administered to unpremedicated dogs in increasing and decreasing concentrations while normal pulmonary ventilation was rigidly maintained. Myocardial contractlity, blood pressure, pulse rate, electrocardiogram, and electroencephalogram were recorded continuously.

A progressive decrease in contractile force of the heart muscle resulted as the inhaled concentration of methoxyflurane increased. A parallel decrease in systolic, diastolic, and pulse pressure occurred. Sinus bradycardia and an alteration in repolarization of cardiac muscle accompanied the dynamic changes. A lag occurred in recovery of all cardiovascular functions and the EEG following withdrawal of the agent. Burst suppression appeared when hypotension below $90 \mathrm{~mm}$. $\mathrm{Hg}$ occurred.

A comparison of the results of this study with those previously reported is presented. 


\section{RÉSUMÉ}

Nous avons fait inhaler à des chiens non prémédiqués des concentrations croissantes et décroissantes de méthoxyflurane alors que nous maintenions, par ventilation artificielle, un taux de $\mathrm{CO}_{2}$ de 5.6 pour cent à la fin de l'expiration. De façon continuelle, nous avons mesuré la contractilité ventriculaire à l'aide d'un dynamomètre ad hoc. Nous avons également enregistré, de façon continue, la pression artérielle, le pouls, les tracés: électrocardiographique et électroencéphalographique.

Nous avons observé que la force de contraction du myocarde diminuait à mesure qu'augmentait la concentration des vapeurs du méthoxyflurane. Si la concentration des vapeurs atteignait 2 pour cent, la force de contraction était diminuée de 48 pour cent. Les pressions-systolique, diastolique et la pression du pouls-diminuaient parallèlement. Les modifications observées à la pression systolique étaient comparables aux modifications observées à la force de contraction. En même temps quapparaissaient ces modifications dynamiques, on pouvait observer l'existence d'une bradycardie et une modification de lá repolarisation du muscle cardiaque.

A mesure que l'anesthésie s'approfondissait, l'activité rapide à bas voltage du tracé électroencéphalographique se modifiait en ondes lentes à haut voltage. En anesthésie profonde, l'activité rapide concomitante disparaissait. On observait fréquemment des absences d'ondes que nous avons attribuées à l'hypotension artérielle. Lorsque la pression artérielle demeurait au-dessus de $90 \mathrm{~mm}$. $\mathrm{Hg}$, ces absences n'apparaissaient pas.

Après avoir discontinué l'administration de l'agent, il s'écoulait un certain temps avant que les fonctions cardiovasculaires et l'activité électroencéphalographique ne réapparaissent.

\section{ACKNOWLEDGMENTS}

Methoxyflurane (Penthrane) was generously provided by the Medical Department, Abbott Laboratories, North Chicago, Illinois.

This study was supported in part by United States Public Health Service Grant HE-01983-09.

\section{REFERENCES}

1. Artusio, J. F. JR. \& Van Poznak, A. Clinical Evaluation of Methoxyflurane in Man. Fed. Proc. 19: 273 (1960).

2. Artusio, J. F. Jr.; Van Poznak, A.; Hunt, R. E.; Trers, F. M.; \& Alexander, M. A. Clinical Evaluation of Methoxyflurane in Man. Anesthesiology 21: 512 (1960).

3. Van Poznak, A. \& Artusio, J. F. JR. Series of Fluorinated Ethers. Fed. Proc. 19: 273 (1960).

4. North, C.; Knox, P. R.; Vartanian, V.; \& Stephen, C. R. Respiratory, Circulatory and Hepatic Effects of Methoxyflurane in Dogs. Anesthesiology 22: 139 (1961).

5. Stebecker, K. L.; Jumes, M.; Bamfonth, B. J.; \& Orthr, O. S. The Respiratory Effect of Methoxyflurane on Dog and Man. Anesthesiology 22: 143 (1961).

6. Andersen, N. \& Andersen, E. W. Methoxyflurane, a New Volatile Anaesthetic Agent. Acta Anaesth. Scand. 5: 179 ( 1961 ). 
7. Price, H. L.; Linde, H. W.; Jones, R. E.; Black, G. W.; \& Phice, M. L. Sympathoadrenal Responses to General Anesthesia in Man and Their Relation to Hemodynamics. Anesthesiology 20:563 (1959).

8. Bontface, K. J.; Brodie, O. J.; Walton, R. P. Resistance Strain Gauge Arches for Direet Measurement of Heart Contractile Force in Animals. Proc. Soc. Exper. Biol. \& Med. 84: 263 (1953).

9. LANNEK, N. A Clinical and Experimental Study of the EKG in Dogs. Med. Clin. Roy. Yet. Coll. Stockholm (1949).

10. Thomason, R.; Light, G.; \& Holaday, D. A. Methoxyflurane Anesthesia: A Clinical Appraisal. Anesth. \& Analg. 41: 225 ( 1962).

11. Bagwell, E. E.; Woods, E. F.; \& Gadsden, R. H. Blood Levels and Cardiovascular Dynamics during Methoxyllurane Inhalation in Dogs. Anesthesiology 23: 243 (1962).

12. Wyant, G. M.; Chang, C. A.; \& Rapicavoli, E. Methoxyflurane (Penthrane): A Laboratory and Clinical Study. Canad. Anaesth. Soc. J. 8: 477 (1961).

13. Dobmon, A. B. \& Fedonuk, S. Comparison of the Cardiovascular, Respiratory and Metabolic Effects of Methoxyflurane and Halothane in Dogs. Anesthesiology 22: 355 (1961).

14. Campbel, M. W.; Hvolbol, A. P.; \& Brechner, V. L. Penthrane, a Clinical Evaluation in 50 Cases, Anesth. \& Analg. 41:134 (1962).

15. Knox, P. R.; Nonth, W. C.; \& Stepien, C. R. Methoxyflurane-A Clinical Evaluation. Anesthesiology 23: 238 (1962). 